\title{
Centrosomal abnormalities, multipolar mitoses, and chromosomal instability in head and neck tumours with dysfunctional telomeres
}

\section{Gisselsson*,', T Jonson', C Yu', C Martins², N Mandahl', J Wiegant', Y Jin', F Mertens' and C Jin'}

'Department of Clinical Genetics, University Hospital, SE-22I 85 Lund, Sweden; ' Laboratory of Cytometry and Cytogenetics, Portuguese Institute of Oncology, Lisboa, Portugal; ${ }^{3}$ Laboratory of Cytochemistry and Cytometry, Department of Molecular Cell Biology, Leiden University Medical Center, Leiden, the Netherlands

Carcinomas of the head and neck typically exhibit complex chromosome aberrations but the underlying mutational mechanisms remain obscure. Evaluation of cell division dynamics in low-passage cell lines from three benign and five malignant head and neck tumours revealed a strong positive correlation between multipolarity of the mitotic spindle and the formation of bridges at anaphase in both benign and malignant tumours. Cells exhibiting a high rate of mitotic abnormalities also showed several chromosome termini lacking TTAGGG repeats and a high frequency of dicentric chromosomes. Multicolour karyotyping demonstrated a preferential involvement in structural rearrangements of chromosomes with deficient telomeres. The majority of malignant, mitotically unstable tumours expressed the reverse transcriptase subunit of telomerase. These data indicate that some of the genomic instability in head and neck tumours is initiated by telomere dysfunction, leading to the formation of dicentric chromosomes. These form chromosome bridges at mitosis that could prevent the normal anaphasetelophase transition. In turn, this may cause an accumulation of centrosomes and mitotic multipolarity. Telomerase expression does not confer total stability to the tumour genome but could be crucial for moderating the rate of chromosomal evolution. British Journal of Cancer (2002) 87, 202 -207. doi:I0.1038/sj.bjc.6600438 www.bjcancer.com (c) 2002 Cancer Research UK

Keywords: squamous cell carcinoma; pleomorphic adenoma; telomere; breakage-fusion-bridge cycle; centrosome

Carcinoma of the head and neck is the sixth most common malignancy world-wide (Parkin et al, 1988). Whereas tumours confined to the oral cavity and the airways are predominantly squamous cell carcinomas, tumours of the salivary glands are histologically more heterogeneous, with the most common type being pleomorphic adenoma (PA). Head and neck squamous cell carcinomas (HNSCC) are characterised by complex, non-random chromosomal changes. Common structural rearrangements include isochromosomes for $1 \mathrm{q}, 3 \mathrm{q}, 5 \mathrm{p}$, and $8 \mathrm{q}$, deletions of $3 \mathrm{p}$, and homogeneously staining regions containing amplified material from $11 \mathrm{q} 13$ (Van Dyke et al, 1994; Jin et al, 1995). Losses and gains of whole chromosomes are also common, including $-\mathrm{Y},+7$ $-17,-18,+20$, and -21 . Salivary gland PA, on the other hand, typically display simple structural changes of $8 \mathrm{q} 11-12$ or $12 \mathrm{q} 13-15$, leading to dysregulated expression of the PLAG1 and HMGA2 (formerly HMGIC) genes, respectively (Geurts et al, 1997; Kas et al, 1997). Rearrangements of PLAG1 have also been detected in malignant salivary gland tumours, carcinoma ex pleomorphic adenomas, usually together with additional cytogenetic changes (Jin et al, 2001).

The mechanisms behind chromosome aberrations in head and neck tumours are obscure. Mitotic instability including breakage and/or nondisjunction of chromosomes has been demonstrated in established cell lines from HNSCC (Saunders et al, 2000). Recently, it has been suggested that this type of chromosome instability could be triggered by telomere dysfunction, leading to instability of chromosome termini (Artandi et al, 2000; Gisselsson

*Correspondence: D Gisselsson; E-mail: david.gisselsson@klingen.lu.se Received 22 February 2002; revised I May 2002; accepted 8 May 2002 et al, 2001b). Another mode of mitotic instability found in HNSCC cell lines consists of multipolar cell divisions, possibly caused by supernumerary centrosomes (Saunders et al, 2000). Little is known about the relation between centrosome abnormalities and mitotic multipolarity, on the one hand, and telomeric dysfunction and mitotic chromosome breakage on the other. However, the fact that structural and numerical chromosome abnormalities occur together in many tumours indicates that these processes may be related mechanistically. This study is an attempt to elucidate some of the events leading to complex karyotypic abnormalities in head and neck tumours by parallel evaluation of cell division figures, centrosomal configuration, telomere status, and telomerase expression in low-passage cell lines from HNSCC and PA.

\section{MATERIALS AND METHODS}

\section{Cell culture}

Biopsies from five HNSCC and three PA (Table 1) were minced with scissors and disaggregated overnight in $180 \mathrm{U} \mathrm{ml}^{-1}$ collagenase II (Cooper Biomedical, Lakewood, NJ, USA). The resulting suspension was plated on vitrogen-coated chamber slides or in culture flasks. Cells were cultured in keratinocyte serumfree medium (GIBCO 041 - $17005 \mathrm{M}$ ), supplemented with $0.23 \mathrm{mg} \mathrm{ml}^{-1}$ L-glutamine, $100 \mathrm{IU} \mathrm{ml}^{-1}$ penicillin, $0.2 \mathrm{mg} \mathrm{ml}^{-1}$ streptomycin, and $2.5 \mu \mathrm{g} \mathrm{ml}^{-1}$ amphotericin. Cell culture morphology was assessed in an inverted microscope. After partial harvesting and a first chromosome banding analysis, the remaining cells were further cultured until $90 \%$ confluence (3-5 days) and then subcultured 3-5 times before analysis, except case five, which 
Table I Chromosomal instability in head and neck tumours

\begin{tabular}{|c|c|c|c|c|c|c|c|}
\hline Case No. & Diagnosis and location & Karyotype & $\begin{array}{l}\text { Anaphase } \\
\text { bridges }\end{array}$ & dic or tas ${ }^{a}$ & $\begin{array}{c}\text { TTAGGG- } \\
\text { negative } \\
\text { termini }^{\text {b }}\end{array}$ & $\begin{array}{l}\text { Multipolar } \\
\text { mitoses }\end{array}$ & $\begin{array}{c}\text { TERT } \\
\text { expression }\end{array}$ \\
\hline I & $\begin{array}{l}\text { pleomorphic adenoma, } \\
\text { parotid gland }\end{array}$ & $46, X X, t(8 ; 8)(p 23 ; q \mid 2)$ & $17 \%$ & $26 \%$ & 5 & $4 \%$ & No \\
\hline 2 & $\begin{array}{l}\text { pleomorphic adenoma, } \\
\text { parotid gland }\end{array}$ & $\begin{array}{l}\text { 46,XY,ins }(8 ; \mid 4)(q \mid 2 ; q 24 q 32) \\
\operatorname{der}(\mid 4) t(8 ; \mid 4)(q \mid 2 ; q 24)\end{array}$ & $5 \%$ & $5 \%$ & 0.8 & $0.5 \%$ & No \\
\hline 3 & $\begin{array}{c}\text { pleomorphic adenoma, } \\
\text { parotid gland }\end{array}$ & $\begin{array}{c}46, X X, \operatorname{der}(12) \operatorname{inv}(12)(q \mid 2 q 21) \operatorname{inv}(12) \\
(q 2 \mid q 24)\end{array}$ & $11 \%$ & $29 \%$ & 3 & $0 \%$ & No \\
\hline 4 & $\begin{array}{c}\text { squamous cell carcinoma, } \\
\text { sinus maxillaris }\end{array}$ & $\begin{array}{c}\text { 45,X,-X,del }(6)(q \mid 5), \operatorname{der}(7) t(3 ; 7) \\
(q 2 \mid ; p 22) / 46, \operatorname{idem}(5)(q||)\end{array}$ & $4 \%$ & 0 & 0.8 & $0.3 \%$ & Yes \\
\hline 5 & $\begin{array}{c}\text { squamous cell carcinoma, } \\
\text { oral cavity }\end{array}$ & Complex & $11 \%$ & $25 \%$ & 8 & $1 \%$ & Yes \\
\hline 6 & $\begin{array}{c}\text { squamous cell carcinoma, } \\
\text { larynx }\end{array}$ & Complex & $28 \%$ & $32 \%$ & 8 & $7 \%$ & No \\
\hline 7 & $\begin{array}{c}\text { squamous cell carcinoma, } \\
\text { cheek }\end{array}$ & Complex & $29 \%$ & $32 \%$ & 18 & $7 \%$ & Yes \\
\hline 8 & $\begin{array}{c}\text { squamous cell carcinoma, } \\
\text { nose, metastasis }\end{array}$ & Complex & $36 \%$ & $55 \%$ & 26 & $8 \%$ & Yes \\
\hline
\end{tabular}

a Proportion of cells carrying at least one dicentric chromosome or telomeric association (tas). ${ }^{\mathrm{b}}$ Mean number of TTAGGG-negative ends/cell.

was subcultured 15 times. As a negative control, dermal fibroblasts subcultured four times were used.

\section{Analysis of mitotic cell morphology}

For analysis of mitotic figures, cells on chamber slides were washed in phosphate-buffered saline (PBS) for $5 \mathrm{~min}$, fixed in methanol: acetic acid $(3: 1)$ at $-20^{\circ} \mathrm{C}$ for $30 \mathrm{~min}$, air-dried, and stained with haematoxylin and eosin. At least 150 anaphase and 150 metaphase cells were analysed in each case.

\section{Centrosome detection}

Cells on chamber slides were washed in PBS for $5 \mathrm{~min}$, fixed in methanol at $-20^{\circ} \mathrm{C}$ for $30 \mathrm{~min}$ and air-dried. The cells were then rehydrated in PBS for 5 min, blocked with $1 \%$ bovine serum albumin in PBS for $15 \mathrm{~min}$, and incubated with murine monoclonal anti- $\gamma$-tubulin antibodies (GTU-88, Sigma, St. Louis, MS, USA), diluted 1:40 in blocking buffer for $30 \mathrm{~min}$. After washing three times for $3 \mathrm{~min}$ in PBS, secondary 1:20 biotinylated anti-mouse antibodies (E0354, DAKO A/S, Denmark) were applied for $30 \mathrm{~min}$, followed by washing in PBS three times for $3 \mathrm{~min}$, and incubation with 1:50 streptavidin-Alexa 594 (Molecular Probes, Leiden, the Netherlands). $\beta$-tubulin was detected subsequently, using $1: 40$ dilutions of mouse monoclonal anti- $\beta$-tubulin antibodies (2-28-33, Sigma) followed by anti-mouse antibodies coupled to fluorescein-isothiocyanate (F0232, DAKO A/S). Cells were dehydrated in a $75-85-100 \%$ ethanol series and counterstained with 4',6-diamidine-2'-phenylindole (DAPI). At least 50 cells were evaluated in each case.

\section{Metaphase chromosome analysis}

Cultures were harvested by exposure to $0.01 \mu \mathrm{g} \mathrm{ml}^{-1}$ colchicine for $12-16 \mathrm{~h}$, followed by hypotonic treatment in $0.06 \mathrm{M} \mathrm{KCl}$ for $35 \mathrm{~min}$, and fixation by 3:1 methanol: acetic acid. Chromosome banding was with Wright's stain according to standard methods (Mandahl, 2001). Multicolour karyotyping was performed by the COBRA probe set as previously described (Jin et al, 2001). Telomeric TTAGGG repeats were visualised by fluorescence in situ hybridisation (FISH) with fluorescein-conjugated (CCCTAA $)_{3}$ peptide nucleic acid probes (Landsdorp et al, 1996). Signal intensity was directly quantified by the Cytovision software (Applied
Imaging, Newcastle, UK). Chromosome identification was by computerised inversion and enhancement of DAPI bands. Centromeric regions were detected using the human pan-alpha satellite probe (Cambio, Cambridge, UK). The PLAG1 locus was analysed by PAC clones 233, 234, and 235, kindly provided by Dr J Bullerdiek, Bremen, Germany. At least 20 cells were evaluated in each case.

\section{Detection of the telomerase regulatory subunit}

Cultures parallel to those used for chromosome and cell division analyses were subjected to total RNA extraction and cDNA synthesis according to standard procedures. The reverse transcriptase subunit of telomerase (TERT) was coamplified with an ACTB fragment in a PTC-225 temperature cycler (MJ Research, Cambridge, MA, USA). An initial 5-min step at $96^{\circ} \mathrm{C}$ was followed by 35 cycles at $96^{\circ} \mathrm{C}$ for $30 \mathrm{~s}, 60^{\circ} \mathrm{C}$ for $30 \mathrm{~s}$, and $72^{\circ} \mathrm{C}$ for $1.5 \mathrm{~min}$, and a final extension at $72^{\circ} \mathrm{C}$ for $10 \mathrm{~min}$. Primers for ACTB (Raff et al, 1997) were added after 10 cycles. Amplified products were separated on a $1.8 \%$ agarose gel and visualized by Vista Green nucleic acid gel stain (Amersham Pharmacia, Amersham Place, UK). A 145-bp segment outside the alternatively spliced region was amplified by using the primers TERT F1784 (CGGAAGAGTGTCTGGAGCAA) and TERT R1928 (GGATGAAGCGGAGTCTGGA), and alternative splice products of the TERT transcript were amplified by using the primers TERT F2164 (GCCTGAGCTGTACTTTGTCAA) and TERT R2620 (CGCAAACAGCTTGTTCTCCATGTC) as described (Ulaner et al, 1998).

\section{RESULTS}

\section{Mitotic and centrosomal abnormalities}

Anaphase bridges were found by haematoxylin-eosin staining in all eight cell lines (Table 1; Figure $1 \mathrm{~A}-\mathrm{C}$ ). The four tumours containing the highest number of anaphase bridges (cases 1, 6-8) also exhibited tri-, tetra-, and hexapolar mitotic figures at frequencies of $4 \%-8 \%$ (Figure $1 \mathrm{D}-\mathrm{F}$ ). There was a strong positive correlation (Pearson, $r=0.96, P<0.05$; Figure 2) between the frequencies of bridges and multipolar mitoses. No bridges or multipolar mitoses were found in control cultures of dermal fibroblasts. Immunofluorescence showed one or two centrosomes in the majority of cells in all tumour cases, similar to the pattern seen in fibroblasts. All cell 

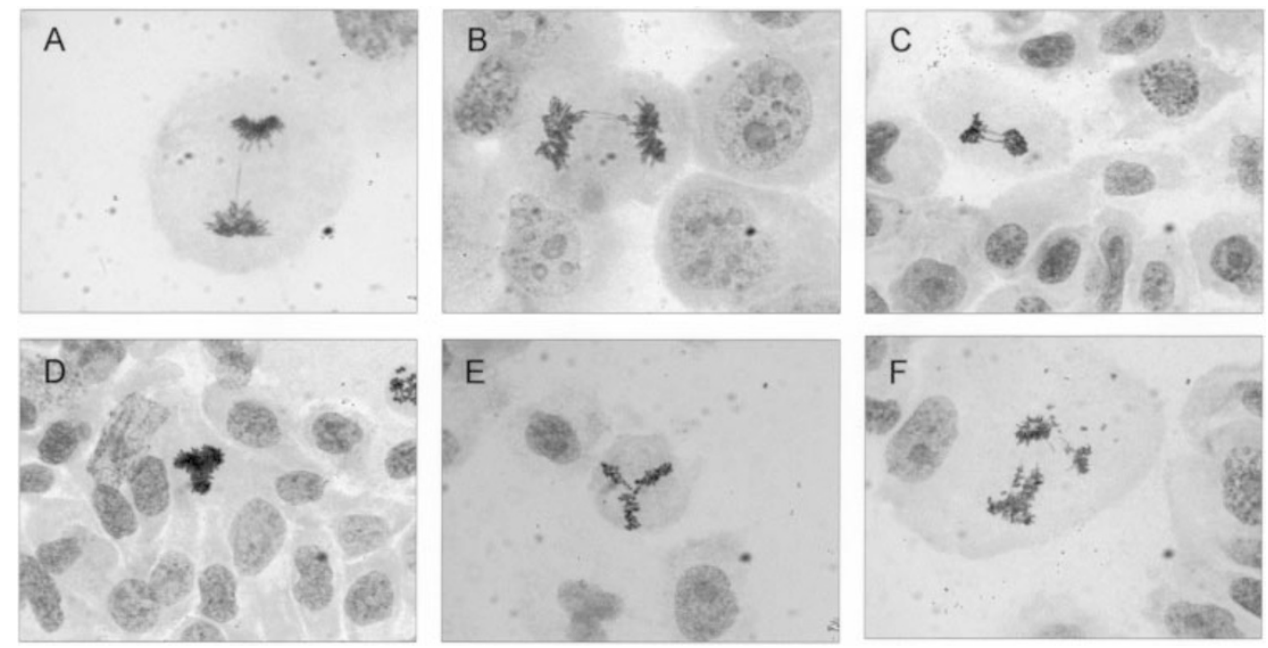

Figure I Broken $(\mathbf{A})$ and intact $(\mathbf{B}$ and $\mathbf{C})$ anaphase bridges in cases 2, 5 and 8, respectively, and multipolar metaphase $(\mathbf{D}$ and $\mathbf{E})$ and anaphase $(\mathbf{F})$ cells in case 8; haematoxylin-eosin staining.

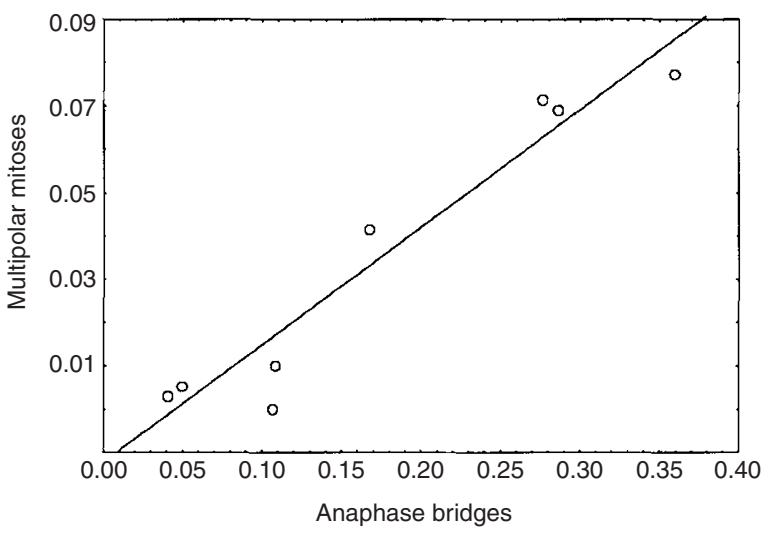

Figure 2 Positive correlation $r=0.96$ (Pearson; $P<0.05$ ) between the frequency of multipolar mitoses and anaphase bridges.

lines also contained a population of cells with large (approximately double-sized) nuclei, showing larger centrosomes, typically with $3-$ 8 centrioles assembled in one cluster. Such clusters were also observed in the fibroblasts, although never containing more than four centrioles per cluster. The cases with the highest rate of bridges and multipolar divisions (cases 1, 6-8) also showed a wide variety of centrosomal configurations, including multiple, scattered or clustered centrosomes at interphase, as well as metaphase cells with several microtubule organising centres (Figure $3 \mathrm{~A}-\mathrm{F}$ ). None of these patterns were observed in the other cell lines or fibroblast cultures. Approximately half of the interphase cells with centrosomal abnormalities were multinucleated.

\section{Metaphase chromosome analysis}

Clonal chromosome abnormalities were present in all tumours (Table 1). Two of the adenomas (cases 1 and 2) contained unbalanced rearrangements of chromosome 8. FISH analysis with probes covering PLAG1 in $8 \mathrm{q} 12$ showed split signals in both cases (data not shown). The third case of adenoma exhibited a double inversion with breaks in $12 \mathrm{q} 12, \mathrm{q} 15$, and $\mathrm{q} 32$. Previous analyses had shown that the 12q15 breakpoint was distal to the HMGA2 gene (Gisselsson et al, 2000). One of the squamous cell carcinomas (case 4) showed rearrangements only of chromosomes 3, 5, 6, and 7. The four other carcinomas had complex karyotypes ( $>$ five changes), including homogeneously staining regions in cases $6-$
8. Additional, non-clonal abnormalities were found in $>5 \%$ of cells in cases 1,3 and $5-8$, but in $<1 \%$ of cells in cases 2 and 4. Pan-alpha satellite detection revealed a low frequency $(<5 \%)$ of dicentric chromosomes (dic) or telomeric associations (tas) in the latter two tumours, whereas the other cases showed dic or tas in $>25 \%$ of cells. FISH detection of TTAGGG repeats showed a mean of 0.8 ends without signals in cases 2 and 4 , similar to the rate in fibroblasts (0.5). The other cases showed between 3 and 26 TTAGGG-negative chromosome ends per cell. The frequency of anaphase bridges was positively correlated to both the mean number of TTAGGG-negative termini $(r=0.90 ; P<0.05)$ and the frequency of cells with dic/tas $(r=0.88 ; P<0.05)$.

Since case 1 was a benign tumour with a single clonal abnormality but nonetheless showed a very high rate of anaphase bridges and multipolar mitoses, it was selected for a more detailed analysis. G-banding of cells from passage 3 revealed non-clonal abnormalities in 11/30 cells analysed, the majority of which were telomeric associations. In the primary culture, G-banding had shown nonclonal abnormalities in 18/100 cells. Multicolour karyotyping of cells from passage 3 corroborated these results, showing abnormalities in addition to the $t(8 ; 8)$ in $13 / 30$ cells (Figure $3 \mathrm{G}, \mathrm{H}$ ), approximately half of which were telomeric associations. Other aberrations were unbalanced translocations (five cells) and dicentric chromosomes (two cells). Chromosome 15 was most commonly affected by telomeric associations and structural rearrangements, involving $15 \mathrm{p}$ in one cell, $15 \mathrm{q}$ in four cells, and both arms in five cells. Chromosome 19 was the second most commonly involved, being rearranged in three cells. FISH detection of telomere repeat sequences was combined with computerised inversion of DAPI banding in order to measure the distribution of negative ends among chromosomes (Figure 2I,J). The most common negative terminus was $15 \mathrm{q}$ (16/30 cells), followed by $15 p(15 / 30), 9 p(7 / 30), 19 q(6 / 30), 16 p(6 / 30), 21 q(5 / 30) 9 q(4 /$ $30)$, and $19 \mathrm{p}(4 / 30)$.

\section{Expression of the telomerase reverse transcriptase subunit}

Human telomerase activity is determined by the expression of its reverse transcriptase subunit, TERT. However, the TERT transcript is alternatively spliced, and only the expression of full-length messages correlates with enzyme activity (Ulaner et al, 1998). Reverse transcriptase-PCR analysis revealed expression of fulllength TERT in all HNC except in case 6, but in none of the PA (Figure 4). Full-length TERT was also found in thymus, used as a positive control, but not in normal kidney and pancreas, used as negative controls. 

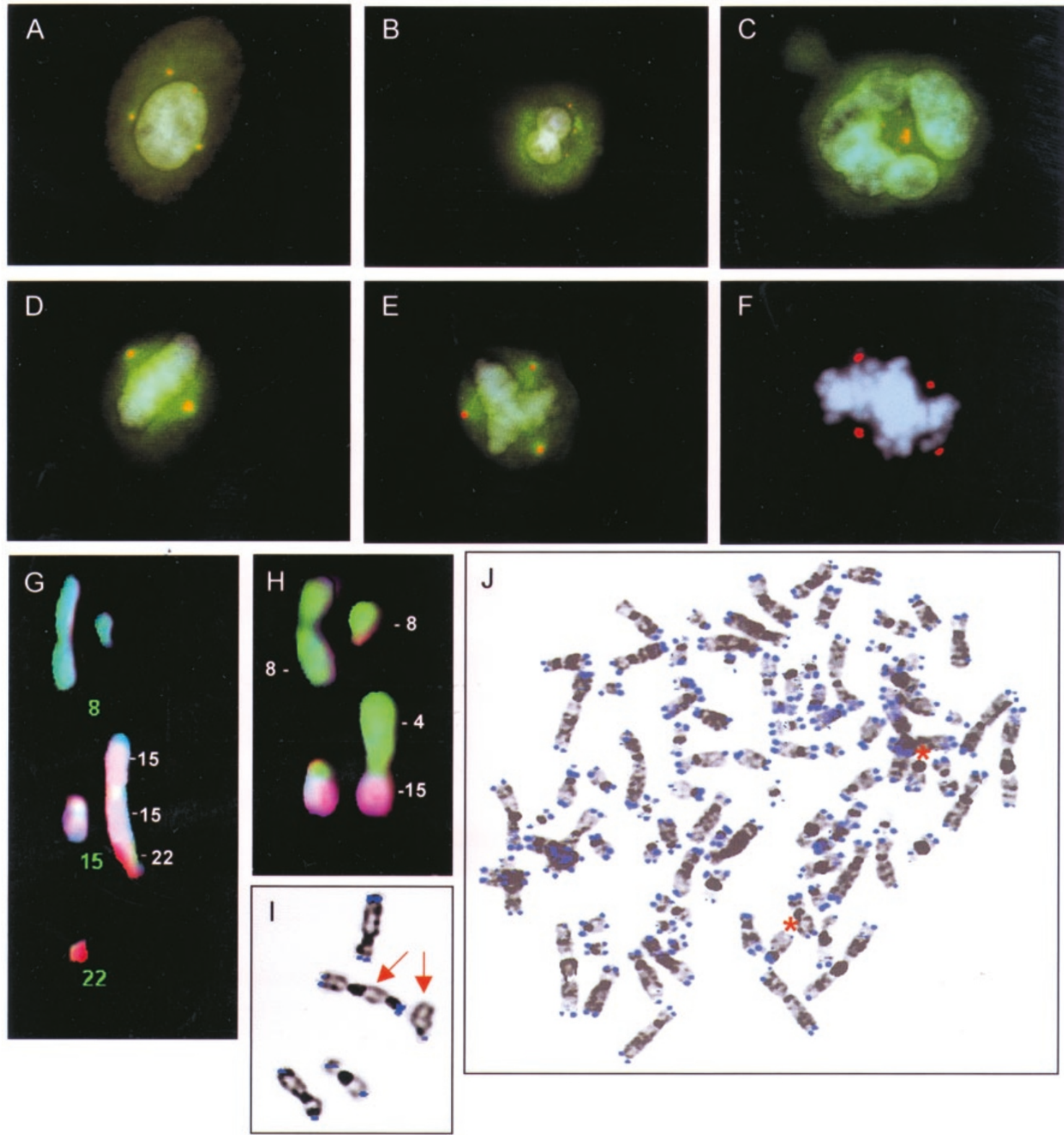

Figure 3 Multiple centrosomes ( $\gamma$-tubulin, red) in mononucleated $(\mathbf{A})$, binucleated $(\mathbf{B})$, and pentanucleated cells $(\mathbf{C})$ in cases I, 2, and 8, respectively. Normal (D) and multipolar (E and $\mathbf{F})$ mitotic figures in cases 5, 8, and 4, respectively; the $\beta$-tubulin fluor layer (green) has been removed for clarity in (F). Non-clonal telomeric associations between two chromosomes 15 and one chromosome $22(\mathbf{G})$ and an unbalanced 4:15-translocation $(\mathbf{H})$ in addition to the clonal 8;8-translocation ( $\mathbf{G}$ and $\mathbf{H}$, top row) demonstrated by multicolour karyotyping in case I. Another cell from the same case shows absence of TTAGGG signals at the q termini of two chromosomes I5, one of which is involved in a telomeric association (I). In other cells, absence of TTAGGG signals was observed at several termini (J), including I5p and q (asterisks).

\section{DISCUSSION}

An inherent genetic instability in neoplastic cells allows rapid accumulation of mutations favourable to tumour progression. Though several different modes of chromosomal instability have been reported, the underlying molecular mechanisms are poorly known (Lengauer et al, 1998). Multipolar mitoses of various configurations may be caused by an abnormal structure and/or function of the mitotic spindle machinery (Lingle et al, 1998; Lingle and Salisbury, 1999; Ghadimi et al, 2000; Shono et al, 2001). In particular, centrosomal aberrations have been correlated with a number of different genetic abnormalities in tumours, e.g. amplification of STK15 (Zhou et al, 1998), mutations in TP53 (Carroll et al, 1999), and inactivation of BRCA1 (Xu et al, 1999), BRCA2 (Tutt et al,
1999), and GADD45 (Hollander et al, 1999). In adenocarcinomas of the prostate and breast, centrosomal abnormalities are known to increase in parallel to loss of tissue differentiation and the development of aneuploidy (Pihan et al, 2001; Lingle et al, 2002). Furthermore, abnormal centrosome function can be induced by expression of the papilloma virus genes E6 and E7, inhibiting normal TP53 and RB1 activity, respectively (Duensing et al, 2000).

Another mode of mitotic instability consists of the formation of chromosome bridges at anaphase. This phenomenon has recently been described in several tumour types, including pancreatic and ovarian adenocarcinoma, HNSCC (Gisselsson et al, 2000; Saunders et al, 2000), osteosarcoma, and soft tissue sarcoma (Gisselsson et al, 1999). Such bridges may consist of mitotically unstable chromosomes undergoing repeated breakage-fusion-bridge (BFB) cycles, 


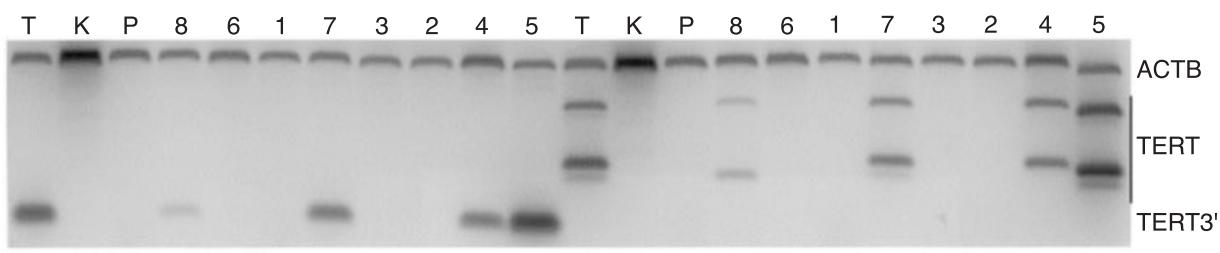

Figure 4 TERT RNA expression measured by reverse transcriptase-PCR with primers outside the alternatively spliced region (TERT3', left) and primers for four alternative splice products (TERT, right). TERT3' expression as well as two major (239 and 42 I bp) and two minor (275 and 457 bp) TERT products are present in thymus (T) and the HNSCC cases 4, 5, 7 and 8, but not in kidney (K), pancreas (P), or the other head and neck tumours; $\beta$-actin (ACTB) was used as internal control.

thus causing massive reorganisation of chromosome structure (McClintock, 1940). However, chromosome banding data have demonstrated that many tumours exhibiting complex structural rearrangements also show a high number of gains and losses of whole chromosomes, suggesting a mechanistic link between structural chromosome instability and the generation of aneuploidy (Mitelman Database of Chromosome Aberration in Cancer, 2002).

In this study, a strong correlation $(r=0.96)$ was found between the frequencies of anaphase bridges and multipolar mitoses in head and neck tumours. One explanation for this could be that both these phenomena depend on one, so far unknown, genetic or epigenetic abnormality. For instance, dysregulation of mitotic control mechanisms could allow both multipolar cell divisions and anaphase bridging with little negative effect on cellular survival (Li and Nicklas, 1995). Alternatively, anaphase bridging and mitotic multipolarity may be correlated because one of the phenomena is directly dependent on the other. Previous investigations have demonstrated that anaphase bridges need not always break at the anaphase-telophase transition; instead they may remain as strings of chromatin between interphase nuclei (Gisselsson et al, 2001a). These internuclear connections could, in turn, prevent cytokinesis and lead to duplication of both chromosome and centrosome number. Depending on the extent to which centrosomal duplication and separation occur in the subsequent cell cycle, the next division could then be orchestrated by two, three, or four centrosomes (Boveri, 1914). In our material, we observed multipolar mitoses clearly containing an increased amount of chromosome material (Figure 3F). However, it seems implausable that the cells with a very high number of nuclei (Figure 3C) could undergo further functional cell divisions; rather they may represent an evolutionary dead end. This is in accordance with the observation that mitoses with five or more poles were very rare $(<0.3 \%)$.

Recent data from aggressive tumours with a high rate of chromosomal instability, such as pancreatic adenocarcinoma and osteosarcoma, have shown that BFB cycles can be triggered by telomere shortening (Gisselsson et al, 2001b). In this study, the frequency of anaphase bridges in HNSCC and PA was, in fact, positively correlated with the number of chromosome ends without TTAGGG signals, indicating that telomere shortening may cause chromosomal instability also in these neoplasms. Furthermore, a detailed multicolour analysis of case 1 demonstrated that the chromosome most commonly lacking termimal TTAGGG repeats was also the one involved in most of the non-clonal aberrations. These chromosome changes were not limited to telomeric associations, but also included dicentrics and other, more complex unbalanced rearrangements. Similar aberrations have been observed in tumours from transgenic mice with dysfunctional telomeres (Artandi et al, 2000).

The present study thus indicates that a single process could lead both to structural and numerical chromosome instability. Telomere shortening will trigger $\mathrm{BFB}$ events that, in turn, may prevent normal cytokinesis and thereby lead to accumulation of centro- somes and multipolar cell divisions. This scenario does not appear to be limited to malignant cells. Cases 1 and 3 were both classified as benign PA, but exhibited a high frequency of anaphase bridges. Investigations of colorectal polyps in mice have shown that BFB events may actually occur already at the dysplastic stage (Rudolph et al, 2001). In man, mitotically unstable ring chromosomes, telomeric associations and anaphase bridges are common in borderline malignant mesenchymal tumours, including giant cell tumours of bone and atypical lipomatous tumours (Mandahl et al, 1998; Gisselsson et al, 1999). However, this is the first study demonstrating all these phenomena in benign lesions. It is noteworthy that cytogenetic alterations similar to those found in case 1 , albeit clonal, are typically present in carcinomas arising from pleomorphic adenomas (Jin et al, 2001). The triggering of mitotic multipolarity by BFB instability may thus be one important mechanism for the development of complex karyotypes and malignant transformation in head and neck tumours.

Full length telomerase reverse transcriptase was expressed in four of the five HNSCCs but in none of the PAs. This is in accordance with earlier studies, showing expression of telomerase in approximately $90 \%$ of malignant tumours (Artandi and DePinho, 2000). The precise role of telomerase in carcinogenesis is not known. It has been suggested that this enzyme is essential for stabilising the genome of malignant tumours. However, in this study there was no difference in the frequency of BFB events between the tumours expressing TERT and those that did not. These results indicate that the stabilising effect of telomerase expression on the tumour genom is incomplete. It should be noted that that stabilisation of chromosome breaks could also be achieved through telomere capture (Slijepcevic and Bryant, 1998; Gisselsson et al, 1999). This does not rule out that TERT expression plays a vital role in tumorigenesis. Clonal expansion in the absence of telomere lengthening implicates extensive erosion of TTAGGG repeats at all chromosome termini. The resulting global genomic instability would probably be incompatible with cellular survival. Even a partial telomere-lengthening effect could then be beneficial by keeping genomic instability at a moderate rate, still allowing evolution of clonal chromosomal imbalances favourable to tumour progression. In this context, drugs inhibiting telomerase activity could be highly effective, potentially tilting the balance from a moderate rate of cytogenetic evolution towards complete mitotic failure.

\section{ACKNOWLEDGEMENTS}

This study was supported by the Swedish Cancer Society, the Swedish Medical Society, the Lennander Foundation, the Crafoord Foundation, and the IngaBritt and Arne Lundberg Foundation. We are grateful to C Lassen and B Strömbeck for excellent technical assistance. 


\section{REFERENCES}

Artandi SE, Chang S, Lee SL, Alson S, Gottlieb GJ, Chin L, DePinho RA (2000) Telomere dysfunction promotes non-reciprocal translocations and epithelial cancers in mice. Nature 406: 641-645

Artandi SE, DePinho RA (2000) A critical role for telomeres in suppressing and facilitating carcinogenesis. Curr Opin Genet Dev 10: 39-46

Boveri T (1914) Zur Frage der Entstehung maligner Tumoren. Jena: Verlag von Gustav Fischer

Carroll PE, Okuda M, Horn HF, Biddinger P, Stambrook PJ, Gleich LL, Li YQ, Tarapore P, Fukasawa K (1999) Centrosome hyperamplification in human cancer: chromosome instability induced by p53 mutation and/or Mdm2 overexpression. Oncogene 18: 1935-1944

Duensing S, Lee LY, Duensing A, Basile J, Piboonniyom S, Gonzalez S, Crum CP, Münger K (2000) The human papillomavirus type 16 E6 and E7 oncoproteins cooperate to induce mitotic defects and genomic instability by uncoupling centrosome duplication from the cell division cycle. Proc Natl Acad Sci USA 97: 10002-10007

Geurts JM, Schoenmakers EF, Roijer E, Stenman G, Van de Ven WJ (1997) Expression of reciprocal hybrid transcripts of HMGIC and FHIT in a pleomorphic adenoma of the parotid gland. Cancer Res 57: 13-17

Ghadimi BM, Sackett DL, Difilippantonio MJ, Schröck E, Neumann T, Jauho A, Auer G, Ried T (2000) Centrosome amplification and instability occurs exclusively in aneuploid, but not in diploid colorectal cancer cell lines, and correlates with numerical chromosomal aberrations. Genes Chromosomes Cancer 27: $183-190$

Gisselsson D, Höglund M, Mertens F, Johansson B, Dal Cin P, Van den Berghe H, Earnshaw WC, Mitelman F, Mandahl N (1999) The structure and dynamics of ring chromosomes in human neoplastic and nonneoplastic cells. Hum Genet 104: 315-325

Gisselsson D, Pettersson L, Höglund M, Heidenblad M, Gorunova L, Wiegant J, Mertens F, Dal Cin P, Mitelman F, Mandahl N (2000) Chromosomal breakage-fusion-bridge events cause genetic intratumor heterogeneity. Proc Natl Acad Sci USA 97: 5357-5362

Gisselsson D, Björk J, Höglund M, Mertens F, Dal Cin P, Åkerman M, Mandahl N (2001a) Abnormal nuclear shape in solid tumors reflects mitotic instability. Am J Pathol 158: 199-206

Gisselsson D, Jonson T, Petersén A, Strömbeck B, Dal Cin P, Höglund M, Mitelman F, Mertens F, Mandahl N (2001b) Telomere dysfunction triggers extensive DNA fragmentation and evolution of complex chromosome abnormalities in human malignant tumours. Proc Natl Acad Sci USA 98: $12683-12688$

Hollander MC, Sheikh MS, Bulavin DV, Lundgren K, Augeri-Henmueller L, Shehee R, Molinaro TA, Kim KE, Tolosa E, Ashwell JD, Rosenberg MP, Zhan Q, Fernandez-Salguero PM, Morgan WF, Deng CX, Fornace Jr AJ (1999) Genomic instability in Gadd45a-deficient mice. Nat Genet 23: $176-184$

Jin C, Martins C, Jin Y, Wiegant J, Wennerberg J, Dictor M, Gisselsson D, Strömbeck B, Fonseca I, Mitelman F, Tanke HJ, Höglund M, Mertens F (2001) Characterization of chromosome aberrations in salivary gland tumors by FISH, including multicolor COBRA-FISH. Genes Chromosomes Cancer 30: $161-167$

Jin Y, Mertens F, Jin C, Åkervall J, Wennerberg J, Gorunova L, Mandahl N, Heim S, Mitelman F (1995) Nonrandom chromosome abnormalities in short-term cultured primary squamous cell carcinomas of the head and neck. Cancer Res 55: 3204-3210

Kas K, Voz ML, Roijer E, Åstrom AK, Meyen E, Stenman G, Van de Ven WJ (1997) Promoter swapping between the genes for a novel zinc finger protein and beta-catenin in pleiomorphic adenomas with $\mathrm{t}(3 ; 8)(\mathrm{p} 21 ; \mathrm{q} 12)$ translocations. Nat Genet 15: $170-174$

Landsdorp PM, Verwoerd NP, van de Rijke FM, Dragowska W, Little M-T, Dirks RW, Raap AK, Tanke HJ (1996) Heterogeneity of telomere length of human chromosomes. Hum Mol Genet 5: 685-691

Lengauer C, Kinzler KW, Vogelstein B (1998) Genetic instabilities in human cancers. Nature 396: 643-649

Li X, Nicklas RB (1995) Mitotic forces control a cell-cycle checkpoint. Nature 373: $630-632$
Lingle WL, Lutz WH, Ingle JN, Maihle NJ, Salisbury JL (1998) Centrosome hypertrophy in human breast tumors: implications for genomic stability and cell polarity. Proc Natl Acad Sci USA 95: 2950-2955

Lingle WL, Salisbury JL (1999) Altered centrosome structure is associated with abnormal mitoses in human breast tumors. Am J Pathol 155: $1941-1951$

Lingle WL, Barrett SL, Negron VC, D’Assoro AB, Boeneman K, Liu WG, Whitehead CM, Reynolds C, Salisbury JL (2002) Centrosome amplification drives chromosomal instability in breast tumor development. Proc Natl Acad Sci USA 99: 1978-1983

Mandahl N, Mertens F, Willén H, Rydholm A, Kreicbergs A, Mitelman F (1998) Nonrandom pattern of telomeric associations in atypical lipomatous tumors with ring and giant marker chromosomes. Cancer Genet Cytogenet 103: $25-34$

Mandahl N (2001) Cytogenetic analysis of solid tumors. In Human Cytogenetics: A Practical Approach: Malignancy and Acquired Abnormalities, Czepulkowski B, Rooney D (eds) London: Oxford University Press

McClintock B (1940) The stability of broken ends of chromosomes in Zea mays. Genetics 26: $234-282$

Mitelman Database of Chromosome Aberration in Cancer (2002) Mitelman F, Johansson B, Mertens F (eds) http://cgap.nci.nih.gov/Chromosomes/ Mitelman

Parkin DM, Laara E, Muir CS (1988) Estimates of the worldwide frequency of sixteen major cancers in 1980. Int J Cancer 41: 184-197

Pihan GA, Purhoit A, Wallace J, Malhotra R, Liotta L, Doxsey SJ (2001) Centrosome defects can account for cellular and genetic changes that characterize prostate cancer progression. Cancer Res 61: 2212-2219

Raff T, van der Giet M, Endemann D, Wiederholt T, Paul M (1997) Design and testing of beta-actin primers for RT-PCR that do not co-amplify processed pseudogenes. Biotechniques 23: 456-460

Rudolph KL, Millard M, Bosenberg MW, DePinho RA (2001) Telomere dysfunction and evolution of intestinal carcinoma in mice and humans. Nat Genet 28: $155-159$

Saunders WS, Shuster M, Huang X, Gharaibeh B, Enyenihi AH, Petersen I, Gollin SM (2000) Chromosomal instability and cytoskeletal defects in oral cancer cells. Proc Natl Acad Sci USA 97: 303-308

Shono M, Sato N, Mizumoto K, Maehara N, Nakamura M, Nagai E, Tanaka M (2001) Stepwise progression of centrosome defects associated with local tumor growth and metastatic process of human pancreatic carcinoma cells transplanted orthotopically into nude mice. Lab Invest 81: 945 -952

Slijepcevic P, Bryant PE (1998) Chromosome healing, telomere capture and mechanisms of radiation-induced chromosome breakage. Int J Radiat Biol 73: $1-13$

Tutt A, Gabriel A, Bertwistle D, Connor F, Paterson H, Peacock J, Ross G, Ashworth A (1999) Absence of Brca2 causes genome instability by chromosome breakage and loss associated with centrosome amplification. Curr Biol 9: 1107-1110

Ulaner GA, Hu JF, Vu TH, Giudice LC, Hoffman AR (1998) Telomerase activity in human development is regulated by human telomerase reverse transcriptase (hTERT) transcription and by alternate splicing of hTERT transcripts. Cancer Res 58: $4168-4172$

Van Dyke DL, Worsham MJ, Benninger MS, Krause CJ, Baker SR, Wolf GT, Drumheller T, Tilley BC, Carey TE (1994) Recurrent cytogenetic abnormalities in squamous cell carcinomas of the head and neck region. Genes Chromosomes Cancer 9: 192-206

Xu X, Weaver Z, Linke SP, Li C, Gotay J, Wang XW, Harris CC, Ried T, Deng CX (1999) Centrosome amplification and a defective G2-M cell cycle checkpoint induce genetic instability in BRCA1 exon 11 isoform-deficient cells. Mol Cell 3: 389-395

Zhou H, Kuang J, Zhong L, Kuo WL, Gray JW, Sahin A, Brinkley BR, Sen S (1998) Tumour amplified kinase STK15/BTAK induces centrosome amplification, aneuploidy and transformation. Nat Genet 20: 189-193 